\title{
Correction to: Sources of creativity stimulation for designing the next generation of technical systems: correlations with R\&D designers' performance
}

\author{
Sara Saliminamin ${ }^{1} \cdot$ Niccolo Becattini $^{1} \cdot$ Gaetano Cascini $^{1}$
}

Published online: 7 January 2019

๑) Springer-Verlag London Ltd., part of Springer Nature 2019

\section{Correction to: Research in Engineering Design https://doi.org/10.1007/s00163-018-0299-2}

Author would like to make corrections in the original publication. Author would like to add a reference to the part 4.3.1 (page 11, in the middle of line 12). The stimuli based on the technical trends of evolution were five stimuli that three of them were ready as TRIZ material course (Souchkov 2017) and two others were prepared by authors.

The reference to the added citation is:
Souchkov V (2017) Training course handbook on TRIZ training for technology and engineering. ICG Training \& Consulting, Enschede, p 284.

Publisher's Note Springer Nature remains neutral with regard to jurisdictional claims in published maps and institutional affiliations. 